\title{
AIRCRAFT ELECTRIC MACHINES
}

\author{
Martin SCHRÖTTER*, František ADAMČÍK, Natália GECEJOVÁ \\ Department of Avionics, Faculty of Aeronautics, Technical University of Kosice, 04001 Košice, \\ Slovakia \\ Olena KOZHOKHINA \\ Department of avionics, Faculty of Air Navigation, Electronics and Telecommunications, National \\ Aviation University, 03058 Kyiv, Ukraine \\ *Corresponding author. E-mail: martin.schrotter@tuke.sk
}

\begin{abstract}
Current trend in aviation is to increase efficiency of all the aircraft's systems. This leads to a reduction of fuel consumption which has also positive effect on emissions. One possibility how to reach this aim is to replace hydraulic and pneumatic system with an electrical power system. Because many on-board electrical loads are in the form of electrical drives, the special attention is given to electric motors and their electronic speed controllers / power converters. Furthermore, electric motors suitable for traction/propulsion are presented. Moreover, the various types of starter/generators suitable for on-board utilisation are compared in the paper.
\end{abstract}

Keywords: electric machines; starter-generators; more electric aircraft

\section{INTRODUCTION}

There is a strict international requirement for global emission reduction. In aviation sector, the projects like Clean Sky and ICAO Global Coalition for Sustainable Aviation aim to reduce noise and pollution [1]. One way how to reduce emissions produced by aircraft is to decrease its consumption. There are more possibilities how it can be managed: drag reduction, decrease the overall weight, increase the efficiency of gas-turbine engines, increase the efficiency of secondary power systems, or change the design of propulsion system.

Dominant secondary power system in modern aircraft is electrical system, thus its influence on overall aircraft efficiency is evident. Most heavy electrical loads in More Electric Aircraft (MEA) are electric motors.

The aim of the paper is to present the top-most solutions of electric machines used on-board of MEA. The Second chapter presents electric motors used for non-propulsive applications. The Third chapter is dedicated to starter/generators and the Fourth chapter describes electric motors which could be used for traction/propulsion.

\section{ELECTRIC MOTORS - NON-PROPULSIVE APPLICATIONS}

In older aircraft electric motors were used scarcely, mainly for low-power applications as beacon drive, for opening/closing the ram air inlet door, for gyro drive, and for medium-power applications as opening/closing the cargo door, for cooling fans drive, etc. Their power output was only several kilowatts. They were of brushed construction. In DC motors the commutator and brushes served for power transmission from rotor to stator. In AC motors the slip rings and brushes served for field production. Both types of motors often required maintenance due to wear and tear of contacts.

In MEA, electric motors are used also for high-power applications as actuators for control surfaces (Electro Hydrostatic Actuator, Electromechanical Actuator), as drive of compressors for air conditioning system, for opening/closing the thrust reversers, for braking. In the future, electric motors are planned to be used for taxing [2]. 
The construction of modern electric motors is of brushless form, which brings advantages in better reliability and lower maintenance time but on the other hand it requires a complex form of speed control. These motors require the power converters / speed controllers specialised for particular motor's applications.

\subsection{Motors for thrust reversers}

In traditional aircraft power concept thrust reversers were powered by hydraulic actuators. In MEA the electric motor is used. In fact, rotary or linear motors can be used. In case of linear motors, the advantage is, that there is no need to transform rotary movement into a linear movement, thus less components must be used. The field weakening can eliminate mechanical gearing. All this results in lower weight and shorter maintenance.

Normally three to six electric actuators with stroke between 300 and $900 \mathrm{~mm}$ are used per nacelle. The time required for the actuator to move from stop-to-stop position is between 1.5 and 5 second, depending on the size of the engine and power demand ranges between $7 \mathrm{~kW}$ to $109 \mathrm{~kW}$ [3].

There are three types of linear electric motors suitable for thrust reverser actuation, namely synchronous, induction and switched reluctance motors [4]. Permanent magnet motors are not suitable because of harsh environment in engine nacelle, especially high temperature which can cause demagnetization, and heavy vibration which can cause mechanical failure of magnet.

The power converter suitable for thrust reverser electrical actuators consist of unidirectional rectifier (DC-link) and inverter. The bidirectional power converter is not necessary because aircraft electrical power system is not designed to accept power from loads.

\subsection{Motors for environmental control system}

The compressed air which is bled from the engine is normally used for cabin pressurisation and wing anti-icing in traditional aircraft power concept. However, such a solution reduces the power of the engine. Using electrical power instead of pneumatic can reduce extracted power from the engine up to $30 \%$ in a mid-size commercial aircraft $[5,6]$. It is because conventional pneumatic system produces more power than is required during the aircraft operation. On the other hand, electrical system produces only such amount of power which is just required by electrical loads. Speed / performance of motors which drive environmental control system compressors can be easily adjusted with variable frequency.

The large-size aircraft, with 350 passengers will require up to $400 \mathrm{~kW}$ to drive the air compressors' motors [7]. These heavy motors must be soft started otherwise they would cause the distinct voltage drop in power system [8].

As a viable candidate to drive a cabin compressor a three-phase squirrel-cage induction motor is proposed. The typical speed of such a motor is $24,000 \mathrm{rpm}$ [9].

\subsection{Motors for control surface actuators}

In MEA, electromechanical (EMA), electro-hydrostatic (EHA) and electrical backup hydraulic actuators (EBHA) are used. Such actuators require no centralised hydraulic circuit which reduces overall weight of the aircraft, simplifies design, and contributes to shorter maintenance. The load requirements differ significantly according to the size of control surface from several kilowatts for the slats, up to 50-60 kW for the horizontal stabilizers and the rudders [10]. Several types of motors can be used to drive actuators. The most promising ones are Permanent magnet synchronous motors (PMSM) and the Switched Reluctances motors (SRM) [11]. A voltage source inverter or matrix converter can be used as a motor's power converter, however both of them have some drawbacks: DC-link capacitor weight and volume in case of voltage source inverter, and power quality management in case of matrix converter [12]. 


\subsection{Motors for fuel pumps}

In traditional aircraft power concept low-pressure fuel pumps are driven electrically, however highpressure fuel pumps are mechanically driven by the engine. In MEA, these pumps are also driven electrically. The advantage of such a system is easy control of fuel pump speed, which enables exact amount of fuel to be supplied to the engine.

For such an application PMSM with more stator phases are used. More phases ensure safe operation even when fault on one phase occur [13].

\subsection{Motors for steering and taxiing}

The nose wheel steering is currently hydraulically driven in both traditional and more electric aircraft power concepts. However, this system must be powered electrically if electric taxing would be implemented on-board the aircraft. The potential candidates for electrical operation of nose wheel steering are linear actuators that use three-phase axial flux permanent magnets [14]. The aim of electric taxing is to reduce noise and emission produced by main engines and auxiliary power units (APU) during ground operations. According to [15], 56\% of the NOx were from taxi operations at Heathrow airport in 2002.

\subsection{Motors for braking system}

The main difference between traditional hydraulic braking system and electric braking system is in the use of EMA, which consist of motor, roller screw and reduction gear. As a motor for electrical braking a PMSM is used because of its outstanding response and accuracy speed [16].

There is research on regenerative braking system suitable for aircraft $[17,18]$, however only for taxi phase. The problem is extensive power which would be produced during the aircraft landing resulting in very high current induced in the motor. Currently, this system is suitable only for vehicle application [19].

\section{STARTER/GENERATORS}

In traditional aircraft power concept starting of main engines was realised by cartridges, turbostarters - small combustion engine, hydraulic motor, and pneumatic motor. In fact, most of current aircraft still use pneumatic starters. Such a solution requires to place long ducting of bleed air from APU to main engine. Electrical starter represents many advantages to upper mentioned systems higher efficiency, lower weight and volume requirement and faster starting process.

First starter/generators emerged in aviation in the late 1940s. They contribute to weight reduction due to use of one machine instead of separate starter and generator. These machines were DC machines with commutator and brushes which were source of arcing. The power limit of DC machine was restricted to $12-18 \mathrm{~kW}$. Due to power limitation of DC machine a brushed AC generators were introduced with typical power ration $30 \mathrm{kVA}$. Later, they were replaced with brushless AC generators.

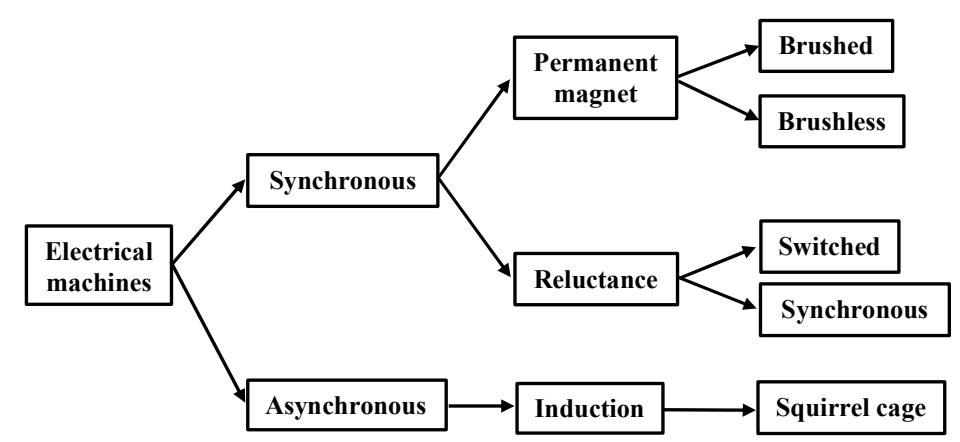

Figure 1 Aircraft starter/generators 
In MEA concept, $\mathrm{AC}$ starter/generators are introduced. In Figure 1, are depicted machines suitable as starter/generators, namely Induction Machine (IM) [20], Synchronous Permanent Magnet Machine (PMSM) [21] and Switched and Synchronous Reluctance Machine (SRM, SynRM) [22, 23]. In Table 1 , the properties of AC starter/generators are summarised.

Table 1 The properties of AC starter/generators [24]

\begin{tabular}{|c|l|l|}
\hline $\begin{array}{c}\text { Electric } \\
\text { machines }\end{array}$ & \multicolumn{1}{|c|}{ Disadvantages } & \multicolumn{1}{c|}{ Advantages } \\
\hline IM & Big air gap affects performance. & $\begin{array}{l}\text { Robustness. } \\
\text { High reliability of operation. }\end{array}$ \\
\hline PMSM & $\begin{array}{l}\text { Limited speed and temperature of operation } \\
\text { due to permanent magnets. } \\
\text { In case of failure, it is hard to demagnetize. }\end{array}$ & $\begin{array}{l}\text { High specific power, lower losses. } \\
\text { Sensor-less construction for harsh } \\
\text { environment. }\end{array}$ \\
\hline SRM & $\begin{array}{l}\text { High torque ripple. } \\
\text { Low torque density. } \\
\text { Poor power factor. }\end{array}$ & $\begin{array}{l}\text { Simple, rugged construction. } \\
\text { High speed and temperature operation. } \\
\text { Fault tolerant. }\end{array}$ \\
\hline
\end{tabular}

\section{ELECTRIC MOTORS - PROPULSIVE APPLICATIONS}

The current effort is to reduce emissions which are produced by combustion of traditional jet fuel in the engine. There are different prospects how it can be managed. One way is to replace traditional jet fuel, based on crude oil, with sustainable fuel, however such a solution does not affect the emissions production very significantly [25]. There are many scientific papers which deal with different alternative fuels [26]. The other way is to use hydrogen as a main fuel in slightly accommodated gas-turbine engines [27,28]. Totally different way is to use full electric propulsion [29]. The main problem with this solution is in electrical energy sources. Batteries have insufficient energy density and fuel cells are still under the research.

The electric motors for propelling the aircraft must have high power-to-weight ratio, at least 10 $\mathrm{kW} / \mathrm{kg}[30]$. In the future, the cryogenic high-specific-power motors are expected to reach this goal. Currently, the hybrid solution is investigated in the form of parallel-hybrid, series-hybrid, and parallel/series-hybrid [31]. It is a different arrangement of gas-turbine and electric motor.

The appropriate candidates for electric propulsion are PMSM, IM and SRM. In case of PMSM surface mounted permanent magnet enables high-speed application with good specific power. The airgap winding topology is preferred due to reduction of iron losses. In case of IM two types of rotors suitable for high specific power applications are suitable - squirrel cage and solid. However, problem for high-speed application of squirrel cage IM is material of the rotor which must withstand mechanical loading and provide good electrical performance. On the other hand, solid rotor IM provide excellent performance (high power, high speed) at the expanse of specific power. In case of SRM which have no windings or permanent magnets on the rotor, all the magneto motive force must be produced on the stator. To ensure high torque the rotor teeth must be salient - this creates a noise. On the other hand, SRM has very robust rotor, which enables high-speed operation and is especially suitable for harsh environment.

The issue of all these high-speed high-specific power machines is the cooling and bearing lubrication. For cooling purposes forced cooling techniques are proposed: forced air through channels, water or oil pumped into cooling jacket around stator frame, liquid bath where whole machine is bathed in dielectric liquids, liquid in direct contact with conductors [32].

\section{CONCLUSION}

To get the best overall efficiency of the aircraft systems, only one form of secondary power can be used. The electric power provides the best properties, not only due to the most convenient distribution system but also due to the fact, that power is consumed only if systems are in use, contrary to 
hydraulic or pneumatic system, which draw power for all the time with excessive power dumped in ambient.

Electric machines are main component of aircraft electrical system. There are three different types of electric machines which are suitable for on-board purposes - PMSM, IM and SRM. Each type has its own advantages and disadvantages but there is one thing which is common to all machines - the low specific power.

To reduce emissions produced by aircraft engine, hydrogen as a fuel is proposed with slight change of gas-turbine engine. In case of electric propulsion, the main drawback is the source of electric power so hybrid electric aircraft concept is proposed.

\section{References}

[1] Available at: https://www.icao.int/environmental-protection/SAC/Pages/learn-more.aspx (3.9.2021)

[2] Arabul, A. Y., Kurt, E., Keskin Arabul, F., Senol, İ., Schrötter, M., Bréda, R., \& Megyesi, D. (2021). Perspectives and Development of Electrical Systems in More Electric Aircraft. International Journal of Aerospace Engineering, 2021.

[3] Johnson, A. T. (2002). Electric thrust reverser actuation systems (No. 2002-01-2950). SAE Technical Paper.

[4] Available at: https://www.boeing.com/features/innovation-quarterly/nov2018/btjactuators.page (3.9.2021)

[5] Available at https://www.boeing.com/commercial/aeromagazine/articles/qtr_4_07/AERO_Q407_article2.pdf (3.9.2021)

[6] Yang, H., Zhang, X., Wang, C., \& Yang, C. (2015). Design Analysis of Power Recovery Systems for Cabin Exhaust Air. Procedia Engineering, 121, 248-255.

[7] Herzog, J. (2006). Electrification of the environmental control system. In Proc. 25th Int. Congr. Aeronaut. Sci. (pp. 1-4).

[8] Hoffman, A. C., Hansen, I. G., Beach, R. F., Plencner, R. M., Dengler, R. P., Jefferies, K. S., \& Frye, R. J. (1985). Advanced secondary power system for transport aircraft.

[9] Cronin, M. J., \& Seid, G. (1984). U.S. Patent No. 4,434,624. Washington, DC: U.S. Patent and Trademark Office.

[10] Robson, P. A., Bradley, K. J., Wheeler, P., Clare, J., De Lillo, L., Gerada, C., ... \& Whitley, C. (2003, June). The impact of matrix converter technology on motor design for an integrated flight control surface actuation system. In IEEE International Electric Machines and Drives Conference, 2003. IEMDC'03. (Vol. 2, pp. 1321-1327). IEEE.

[11] Jack, A. G., Mecrow, B. C., \& Haylock, J. A. (1996). A comparative study of permanent magnet and switched reluctance motors for high-performance fault-tolerant applications. IEEE transactions on industry applications, 32(4), 889-895.

[12] Boglietti, A., Cavagnino, A., Tenconi, A., \& Vaschetto, S. (2009, November). The safety critical electric machines and drives in the more electric aircraft: A survey. In 2009 35th Annual Conference of IEEE Industrial Electronics (pp. 2587-2594). IEEE.

[13] Haylock, J. A., Mecrow, B. C., Jack, A. G., \& Atkinson, D. J. (1998). Operation of a fault tolerant PM drive for an aerospace fuel pump application. IEE Proceedings-Electric Power Applications, 145(5), 441-448.

[14] Brando, G., Dannier, A., Di Noia, L. P., Rizzo, R., \& Hamasaki, S. I. (2016, June). Design of a PMSM for the electric steering of the nose landing gear. In 2016 International Symposium on Power Electronics, Electrical Drives, Automation and Motion (SPEEDAM) (pp. 371-375). IEEE.

[15] Dzikus, N., Fuchte, J., Lau, A., \& Gollnick, V. (2011, September). Potential for fuel reduction through electric taxiing. In 11th AIAA aviation technology, integration, and operations (ATIO) conference, including the AIAA balloon systems conference and 19th AIAA lighter-than (p. 6931). 
[16] Bo, L., \& Li, Y. (2012). Research on simulation of aircraft electric braking system. In Recent Advances in Computer Science and Information Engineering (pp. 301-309). Springer, Berlin, Heidelberg.

[17] Grigore-Müler, O., \& Barbelian, M. (2012, May). Regenerative braking for aircraft landing roll phase using an electric machine. In 2012 13th International Conference on Optimization of Electrical and Electronic Equipment (OPTIM) (pp. 584-593). IEEE.

[18] Heinrich, M. T., Kelch, F., Magne, P., \& Emadi, A. (2015). Regenerative braking capability analysis of an electric taxiing system for a single aisle midsize aircraft. IEEE Transactions on Transportation Electrification, 1(3), 298-307.

[19] Folkson, R. (Ed.). (2014). Alternative fuels and advanced vehicle technologies for improved environmental performance: towards zero carbon transportation. Elsevier.

[20] Jia, Y., \& Rajashekara, K. (2017). Induction machine for more electric aircraft: Enabling new electrical power system architectures. IEEE Electrification Magazine, 5(4), 25-37.

[21] Kulan, M. C., Baker, N. J., \& Widmer, J. D. (2017). Design and analysis of compressed windings for a permanent magnet integrated starter generator. IEEE Transactions on Industry Applications, 53(4), 3371-3378.

[22] Ferreira, C. A., Jones, S. R., Heglund, W. S., \& Jones, W. D. (1995). Detailed design of a 30-kW switched reluctance starter/generator system for a gas turbine engine application. IEEE Transactions on Industry Applications, 31(3), 553-561.

[23] Zhou, B., \& Kong, W. (2021, May). A Novel Control Strategy for Synchronous Reluctance Starter Generator at Low Voltage DC System. In 2021 IEEE 4th International Electrical and Energy Conference (CIEEC) (pp. 1-5). IEEE.

[24] Cao, W., Mecrow, B. C., Atkinson, G. J., Bennett, J. W., \& Atkinson, D. J. (2011). Overview of electric motor technologies used for more electric aircraft (MEA). IEEE transactions on industrial electronics, 59(9), 3523-3531.

[25] Mendez, C., Parthasarathy, R., \& Gollahalli, S. (2012, January). Performance and emission characteristics of a small-scale gas turbine engine fueled with ethanol/Jet A blends. In 50th AIAA Aerospace Sciences Meeting including the New Horizons Forum and Aerospace Exposition (p. 522).

[26] Andoga, R., Főző, L., Schrötter, M., \& Szabo, S. (2021). The Use of Ethanol as an Alternative Fuel for Small Turbojet Engines. Sustainability, 13(5), 2541.

[27] Available online: https://www.rolls-royce.com/innovation/net-zero/decarbonising-complexcritical-systems/hydrogen.aspx (03.12.2021)

[28] Available online: https://www.airbus.com/en/innovation/zero-emission/hydrogen/zeroe (03.12.2021)

[29] Zhang, X., Bowman, C. L., O'Connell, T. C., \& Haran, K. S. (2018). Large electric machines for aircraft electric propulsion. IET Electric Power Applications, 12(6), 767-779.

[30] National Academies of Sciences, Engineering, and Medicine. (2016). Commercial aircraft propulsion and energy systems research: reducing global carbon emissions. National Academies Press.

[31] Wheeler, P., Sirimanna, T. S., Bozhko, S., \& Haran, K. S. (2021). Electric/Hybrid-Electric Aircraft Propulsion Systems. Proceedings of the IEEE, 109(6), 1115-1127.

[32] Popescu, M., Staton, D., Boglietti, A., Cavagnino, A., Hawkins, D., \& Goss, J. (2015, March). Modern heat extraction systems for electrical machines-A review. In 2015 IEEE Workshop on Electrical Machines Design, Control and Diagnosis (WEMDCD) (pp. 289-296). IEEE.

Received 12, 2021, accepted 12, 2021

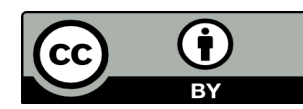

Article is licensed under a Creative Commons Attribution 4.0 International License 